\title{
Six New Phragmalin Limonoids from the Stems of Chukrasia tabularis A. Juss
}

\author{
Yan-Cui Wang ${ }^{1}$, Fan-Dong Kong ${ }^{1}$, Hao Wang ${ }^{1}$, Wen-Li Mei ${ }^{1}$, Shou-Bai Liu ${ }^{2}$, You-Xing Zhao ${ }^{1}$ \\ and Hao-Fu Dai ${ }^{1, *}$ \\ 1 Hainan Key Laboratory for Research and Development of Natural Products from Li Folk Medicine, Institute \\ of Tropical Bioscience and Biotechnology, Chinese Academy of Tropical Agricultural Sciences, \\ Haikou 571101, China; wangyancui.mail@163.com (Y.-C.W.); kongfandong@itbb.org.cn (F.-D.K.); \\ wanghao@itbb.org.cn (H.W.); meiwenli@itbb.org.cn (W.-L.M.); zhaoyouxing@itbb.org.cn (Y.-X.Z.) \\ 2 Institute of Tropical Agriculture and Forestry, Hainan University, Haikou 570228, China; \\ zhiwu19831113@163.com \\ * Correspondence: daihaofu@itbb.org.cn; Tel.: +86-898-6696-1869
}

Academic Editor: Francesco Epifano

Received: 31 October 2018; Accepted: 16 November 2018; Published: 20 November 2018

\begin{abstract}
Six new phragmalin limonoids, named moluccensin Z1 (1), moluccensin Z2 (2), carapanolide Y (3), tabulalin N (4), chukvelutilide A1 (5), and velutinasin J (6), as well as two known compounds, chukvelutilide A (7) and velutinasin D (8) were isolated from the stems of Chukrasia tabularis A. Juss. The structures of the new compounds 1-6 were confirmed by spectroscopic methods, including IR and HRESIMS, as well as 1D and 2D NMR, and by comparisons with the data of known analogues. All compounds were tested for $\alpha$-glucosidase and acetylcholinesterase inhibitory activities. However, none of the compounds was active against $\alpha$-glucosidase and acetylcholinesterase in vitro.
\end{abstract}

Keywords: Chukrasia tabularis A. Juss; Meliaceae; phragmalin limonoid; $\alpha$-glucosidase inhibition activity; acetylcholinesterase inhibitory activity

\section{Introduction}

Chukrasia tabularis A. Juss (Meliaceae) are distributed over the tropical areas of Asia, and its root bark has been used as a traditional medicine for dispelling wind and heat from the body in the Hainan province of China for a long time [1,2]. Previous chemical studies have reported a large number of structurally diverse limonoids from this genus [3], and some of them exhibited anti-inflammatory, antibacterial, insecticidal and cytotoxic activities [4-8]. Phragmalin limonoids such as normal phragmalins and their orthoesters, $\mathrm{C}(15)$-acyl phragmalins, 16,19-dinorphragmalins, 13/14/18-cyclopropanyl phragmalin-type orthoesters, 16-dinorphragmalins, and C(15)-acyl 16-dinorphragmalins are the characteristic components of Chukrasia genus [9-18].

In our previous study, some phragmalin limonoids such as chukbularisin B-E isolated from the big polar part of EtOAc-soluble extract of $C$. tabularis significantly inhibited the $\alpha$-glucosidase [19]. As part of our investigation towards limonoids with novel structures, we continued to study on the small polar part of EtOAc-soluble extract of Chukrasia tabularis A. Juss, which afforded six new phragmalin limonoids, named moluccensin Z1 (1), moluccensin Z2 (2), carapanolide Y (3), tabulalin N (4), chukvelutilide A1 (5), and velutinasin J (6), together with two known compounds chukvelutilide A (7) and velutinasin D (8) (Figure 1). Compounds 1-8 were evaluated for the inhibitory effects on $\alpha$-glucosidase and acetylcholinesterase. In this paper, the isolation, structural elucidation as well as the evaluations focused on the $\alpha$-glucosidase and acetylcholinesterase inhibitory effects of eight limonoids from the stems of $C$. tabularis are described. 


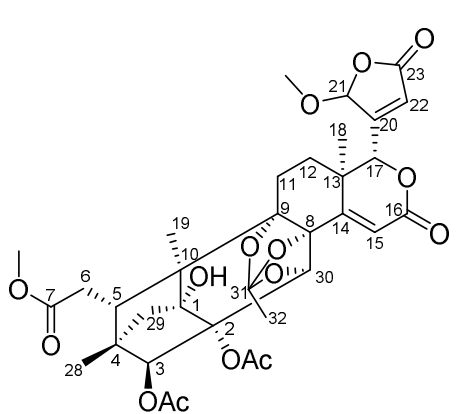

1

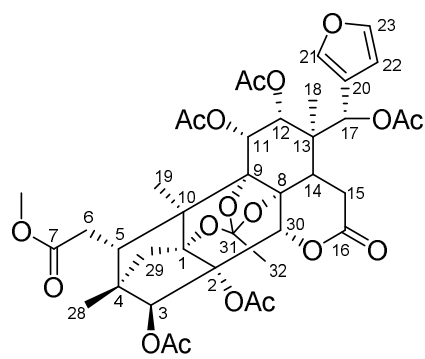

4

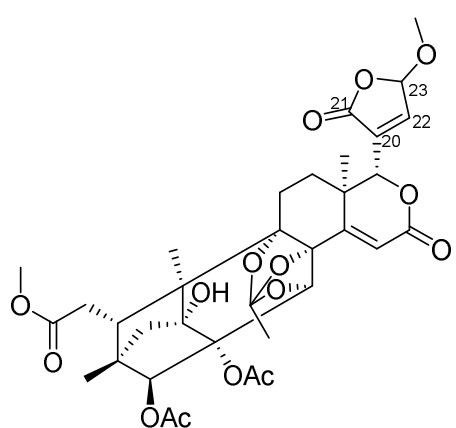

2

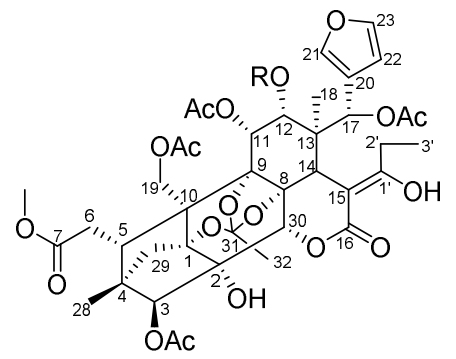

$5 \mathrm{R}=\mathrm{EtCO}$

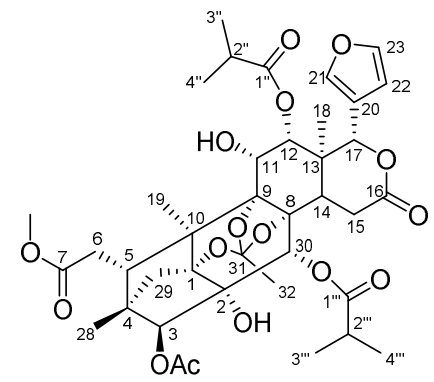

3

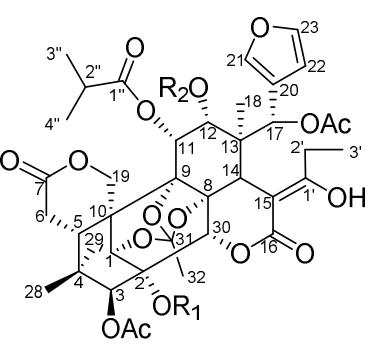

$6 \mathrm{R}_{1}=\mathrm{Ac}, \mathrm{R}_{2}=\mathrm{Ac}$

$8 \mathrm{R}_{1}=\mathrm{H}, \mathrm{R}_{2}=\mathrm{Pr} \mathrm{C} \mathrm{CO}$

Figure 1. The chemical structures of compounds 1-8.

\section{Results and Discussion}

Compound 1, a white amorphous powder, had a molecular formula of $\mathrm{C}_{34} \mathrm{H}_{40} \mathrm{O}_{15}$ as determined by the HRESIMS ion at $m / z 711.2274\left([\mathrm{M}+\mathrm{Na}]^{+}\right.$calcd. 711.2259), corresponding to 15 degrees of unsaturation. The IR absorptions showed the presence of hydroxy group $\left(3528 \mathrm{~cm}^{-1}\right)$ and carbonyl group $\left(1731 \mathrm{~cm}^{-1}\right)$. The ${ }^{1} \mathrm{H}-\mathrm{NMR}$ (Table 1$),{ }^{13} \mathrm{C}-\mathrm{NMR}$ (Table 2) along with the HSQC data of 1 revealed the presence of two methoxy groups, two acetoxy groups, three ester carbons, four methyls, four methylenes, seven methines with four oxygenated, and ten quarternary carbons (two olefinic and four oxygenated). These data were similar to those of moluccensin Y [20], suggesting that compound 1 was also an 8,9,30-phragmalin ortho ester. The main differences between them were the presence of a lactone carbonyl $\left(\delta_{\mathrm{C}} 169.0\right)$, a methoxy $\left(\delta_{\mathrm{H}} 3.56 ; \delta_{\mathrm{C}} 57.3\right)$ and an acetal methine $\left(\delta_{\mathrm{H}} 5.85 ; \delta_{\mathrm{C}} 103.8\right)$ signals and the absence of two olefinic methine signals in 1 compared to moluccensin $\mathrm{Y}$. HMBC correlations between 21-OMe/C-21, H-21/C-20, H-21/C-22, H-21/C-23, H-17/C-20, H-17/C-21, and $\mathrm{H}-17 / \mathrm{C}-22$ indicated that a $\beta$-furyl ring moiety located at $\mathrm{C}-17$ in moluccensin $\mathrm{Y}$ was replaced by a 21-methoxy-20(22)-en-21,23- $\gamma$-lactone moiety in 1 . The remaining substructure was determined to be the same as moluccensin Y based on the 2D NMR data as shown in Figure 2. The nearly identical chemical shifts and $J$-values suggested that compound $\mathbf{1}$ and moluccensin $Y$ shared the same relative configuration. This deduction was confirmed by ROESY correlations of H-3/H-29a, H-11a/Me-18, Me-19/H-11a, H-5/H-11b, H-11b/H-17, H-15/H-30, H-17/H-15, Me-28/H-5, and Me-28/H-29b (Figure 3). Therefore, the structure of $\mathbf{1}$, named moluccensin Z1, was established as shown. 

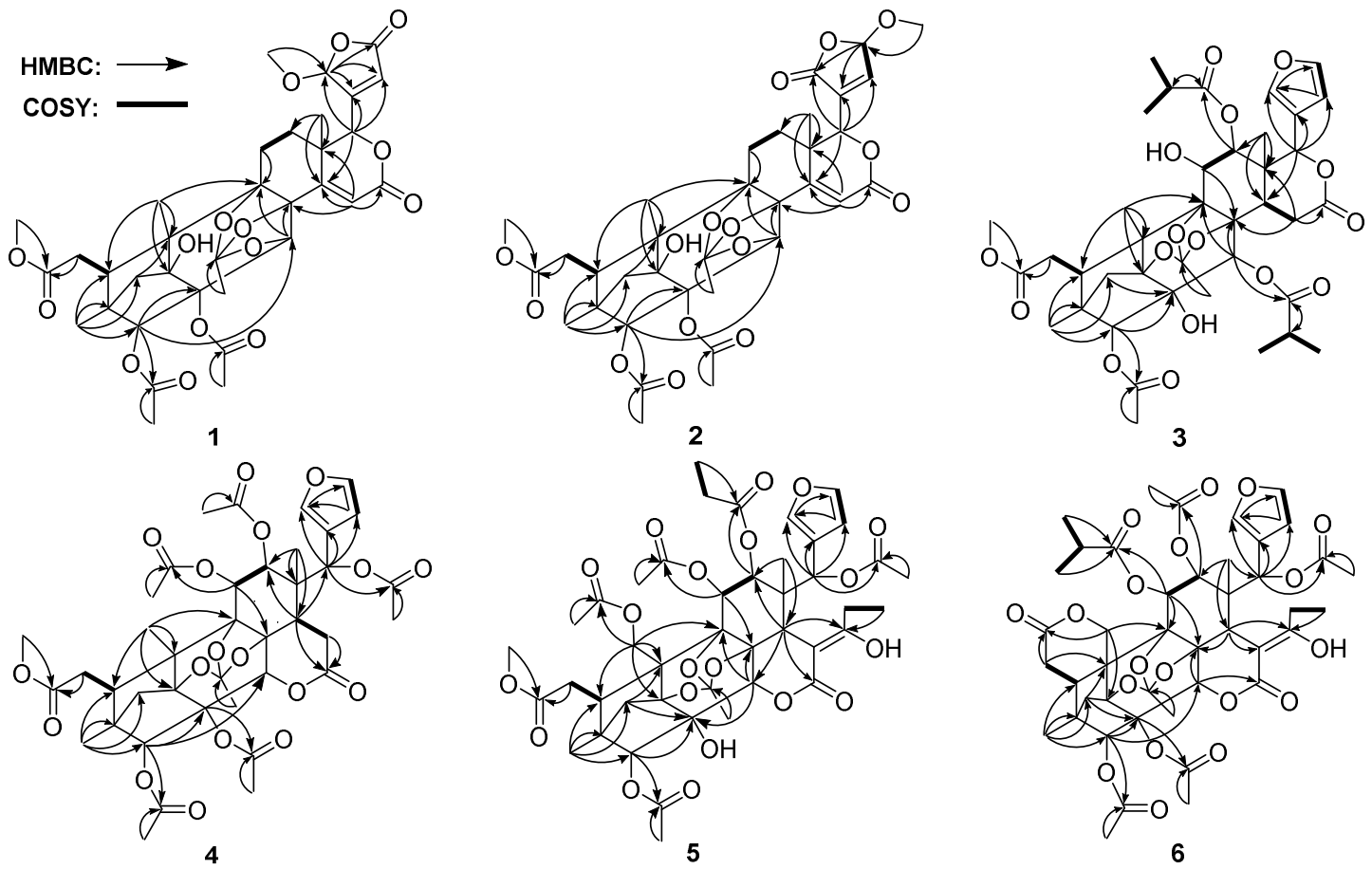

Figure 2. Key HMBC and ${ }^{1} \mathrm{H}_{-}{ }^{1} \mathrm{H}$ COSY correlations for compounds 1-6.
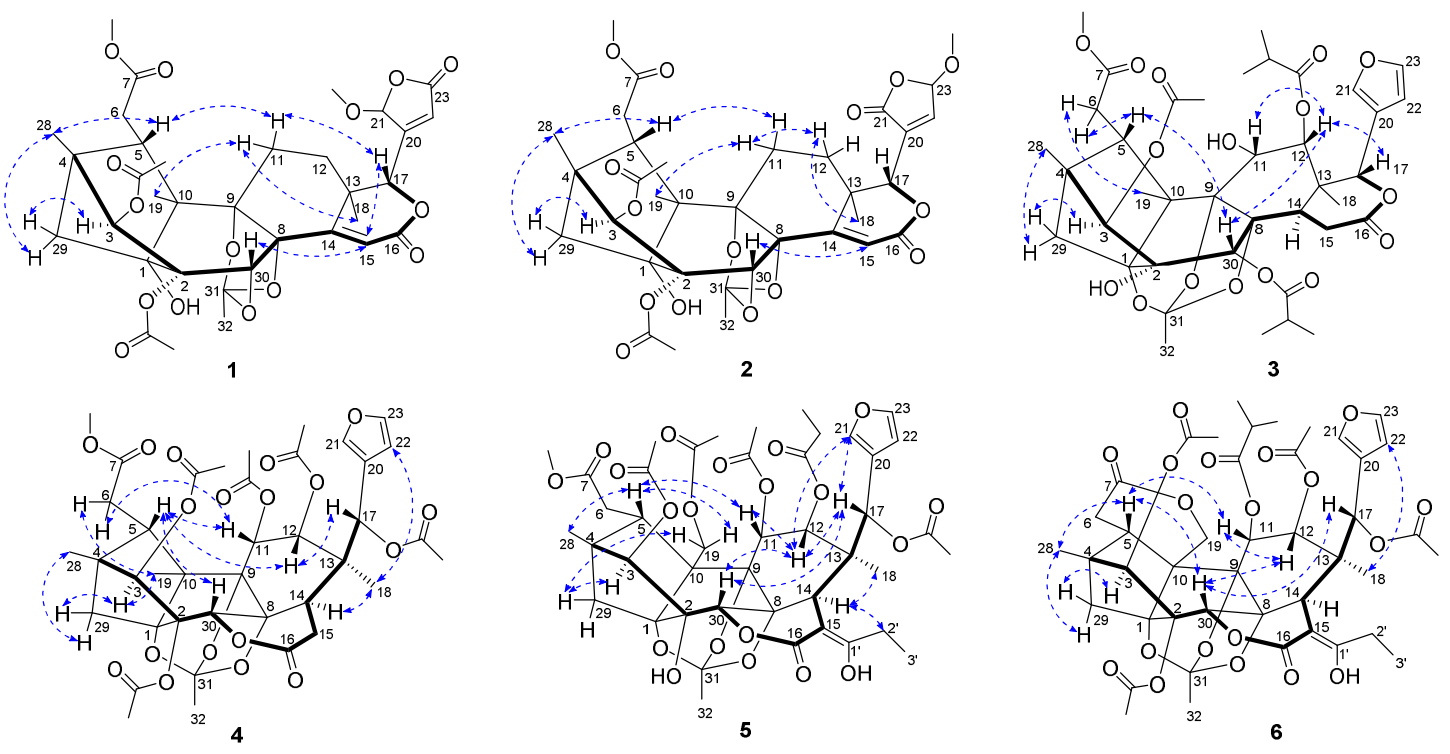

Figure 3. Key ROESY correlations for compounds 1-6.

Compound 2 was obtained as a white amorphous powder. The molecular formula $\mathrm{C}_{34} \mathrm{H}_{40} \mathrm{O}_{15}$ was determined by the pseudomolecular ion peak at $m / z 711.2260\left([\mathrm{M}+\mathrm{Na}]^{+}\right.$calcd. 711.2259$)$ in the HRESIMS, indicating 15 degrees of unsaturation. The IR spectrum of 2 displayed absorptions for hydroxy group at $3545 \mathrm{~cm}^{-1}$ and carbonyl group at $1734 \mathrm{~cm}^{-1}$. The NMR data of 2 (Tables 1 and 2) showed great similarity to those of moluccensin Z1 (1), except for the replacement of the 21-methoxy-20(22)-en-21,23- $\gamma$-lactone moiety located at C-17 in $\mathbf{1}$ by a 23-methoxy-20(22)-en-21,23- $\gamma$-lactone moiety in 2. This deduction was further confirmed by the HMBC correlation between H-17/C-20, H-17/C-21, H-17/C-22, H-23/C-20, H-23/C-21, 23-OMe/C-23, and ${ }^{1} \mathrm{H}-{ }^{1} \mathrm{H}$ COSY correlation of $\mathrm{H}-22 / \mathrm{H}-23$ (Figure 2). The relative configuration of 2 was assigned to be the same as that of $\mathbf{1}$ based on the explanation of ROESY correlations (Figure 3). Thus, the structure of 2, named moluccensin Z2, was elucidated as shown. 
Table 1. ${ }^{1} \mathrm{H}-\mathrm{NMR}(500 \mathrm{MHz})$ data of compounds $\mathbf{1}-\mathbf{3}\left(\mathrm{CDCl}_{3}, \delta_{\mathrm{H}}\right.$ in ppm, $J$ in $\left.\mathrm{Hz}\right)$.

\begin{tabular}{|c|c|c|c|}
\hline Proton & 1 & 2 & 3 \\
\hline 3 & $5.23(\mathrm{~s})$ & $5.24(\mathrm{~s})$ & $4.72(\mathrm{~s})$ \\
\hline 5 & $2.23(\mathrm{~m})$ & $2.30(\mathrm{~m})$ & $3.04(\mathrm{~d}, 10.1)$ \\
\hline $6 a$ & $2.33($ br d, 10.0) & $2.46($ br d, 15.6) & $2.39(\mathrm{dd}, 16.9,10.7)$ \\
\hline $6 b$ & $2.32(\mathrm{br} \mathrm{d}, 10.0)$ & $2.33($ br d, 15.6) & $2.54(\mathrm{br} \mathrm{d}, 16.9)$ \\
\hline $11 a$ & $2.23(\mathrm{~m})$ & $2.17(\mathrm{~m})$ & \\
\hline $11 b$ & $2.01(\mathrm{~m})$ & $1.90(\mathrm{~m})$ & $4.29(\mathrm{~d}, 2.3)$ \\
\hline $12 a$ & $1.45(\mathrm{~m})$ & $1.17(\mathrm{~m})$ & \\
\hline $12 b$ & $1.62(\mathrm{~m})$ & $1.26(\mathrm{~m})$ & $4.54(\mathrm{~d}, 2.3)$ \\
\hline 14 & & & 2.76 (overlap) \\
\hline $15 a$ & & & 2.76 (overlap) \\
\hline $15 b$ & $6.59(\mathrm{~s})$ & $6.61(\mathrm{~s})$ & $3.23(\mathrm{dd}, 17.4,1.5)$ \\
\hline 17 & $5.67(\mathrm{~s})$ & $5.55(\mathrm{~s})$ & $5.66(\mathrm{~s})$ \\
\hline 18 & $1.41(3 \mathrm{H}, \mathrm{s})$ & $1.33(3 \mathrm{H}, \mathrm{s})$ & $1.42(3 \mathrm{H}, \mathrm{s})$ \\
\hline 19 & $1.29(3 \mathrm{H}, \mathrm{s})$ & $1.26(3 \mathrm{H}, \mathrm{s})$ & $1.13(3 \mathrm{H}, \mathrm{s})$ \\
\hline 21 & $5.85(\mathrm{~s})$ & & $7.44(\mathrm{~s})$ \\
\hline 22 & $6.25(\mathrm{~s})$ & $7.37(\mathrm{t}, 1.5)$ & $6.42(\mathrm{dd}, 1.9,0.8)$ \\
\hline 23 & & $5.80(t, 1.5)$ & $7.36(t, 1.9)$ \\
\hline 28 & $0.72(3 \mathrm{H}, \mathrm{s})$ & $0.73(3 \mathrm{H}, \mathrm{s})$ & $0.90(3 \mathrm{H}, \mathrm{s})$ \\
\hline $29 a$ & $1.72(\mathrm{~m})$ & $1.70(\mathrm{~m})$ & $1.78(\mathrm{~d}, 11.5)$ \\
\hline $29 b$ & $1.94(\mathrm{~d}, 11.6)$ & $1.93(\mathrm{~d}, 11.5)$ & $1.89(\mathrm{~d}, 11.5)$ \\
\hline 30 & $5.34(\mathrm{~s})$ & $5.36(\mathrm{~s})$ & $6.12(\mathrm{~s})$ \\
\hline 32 & $1.70(3 \mathrm{H}, \mathrm{s})$ & $1.69(3 \mathrm{H}, \mathrm{s})$ & $1.76(3 \mathrm{H}, \mathrm{s})$ \\
\hline 7-OMe & $3.64(3 \mathrm{H}, \mathrm{s})$ & $3.62(3 \mathrm{H}, \mathrm{s})$ & $3.73(3 \mathrm{H}, \mathrm{s})$ \\
\hline 21/23-OMe & $3.56(3 \mathrm{H}, \mathrm{s})$ & $3.60(3 \mathrm{H}, \mathrm{s})$ & \\
\hline 2-OAc & $2.16(3 \mathrm{H}, \mathrm{s})$ & $2.16(3 \mathrm{H}, \mathrm{s})$ & \\
\hline 3-OAc & $2.08(3 \mathrm{H}, \mathrm{s})$ & $2.11(3 \mathrm{H}, \mathrm{s})$ & $2.28(3 \mathrm{H}, \mathrm{s})$ \\
\hline $12-\mathrm{OCOCHMe} 2$ & & & $2.59(\mathrm{~m}), 1.19(3 \mathrm{H}, \mathrm{d}, 7.2), 1.09(3 \mathrm{H}, \mathrm{d}, 6.8)$ \\
\hline $30-\mathrm{OCOCHMe}$ & & & $2.17(\mathrm{~m}), 0.95(3 \mathrm{H}, \mathrm{d}, 7.0), 0.83(3 \mathrm{H}, \mathrm{d}, 7.0)$ \\
\hline
\end{tabular}

Compound 3, a white amorphous powder, had the molecular formula of $\mathrm{C}_{39} \mathrm{H}_{50} \mathrm{O}_{16}$ as determined by the HRESIMS ion at $m / z 797.3017\left([\mathrm{M}+\mathrm{Na}]^{+}\right.$calcd. 797.2991), which indicated 15 degrees of unsaturation. The IR absorption bands at $3457 \mathrm{~cm}^{-1}$ and $1736 \mathrm{~cm}^{-1}$ suggested the presence of hydroxy and carbonyl groups. Analysis of the ${ }^{1} \mathrm{H}$ - and ${ }^{13} \mathrm{C}-\mathrm{NMR}$ data of 3 (Tables 1 and 2) revealed that it was similar to those of carapanolide $\mathrm{M}$ [21], except for the replacements of the 12-O-acetyl group and 30-O-propionyl group in carapanolide $\mathrm{M}$ by the $12-\mathrm{O}$-isobutyryl group and 30-O-isobutyryl group in 3, which was confirmed by COSY correlations of $\mathrm{H}-4^{\prime \prime \prime} / \mathrm{H}-2^{\prime \prime} / \mathrm{H}-3^{\prime \prime}$ and $\mathrm{H}-4^{\prime \prime \prime} / \mathrm{H}-2^{\prime \prime \prime} / \mathrm{H}-3^{\prime \prime \prime}$ in combination with HMBC correlations of $\mathrm{H}-2^{\prime \prime} / \mathrm{C}-1^{\prime \prime}$ and $\mathrm{H}-2^{\prime \prime \prime} / \mathrm{C}-1^{\prime \prime \prime}$ (Figure 2). The relative configuration of 3 was established to be the same as that of carapanolide M by the ROESY spectrum (Figure 3). Therefore, the structure of $\mathbf{3}$ was elucidated and it was named carapanolide $\mathrm{Y}$.

Compound 4 was isolated as a white amorphous powder. The molecular formula $\mathrm{C}_{39} \mathrm{H}_{46} \mathrm{O}_{18}$ was determined by the HRESIMS ion at $m / z$ 825.2588 ([M $+\mathrm{Na}]^{+}$calcd. 825.2576), which indicated 17 degrees of unsaturation. The IR spectrum of 4 exhibited absorption for carbonyl groups at $1750 \mathrm{~cm}^{-1}$. The ${ }^{1} \mathrm{H}$ - and ${ }^{13} \mathrm{C}-\mathrm{NMR}$ data of 4 (Tables 2 and 3) were similar to those of tabulalin C [22]. Compared with tabulalin $\mathrm{C}, 4$ had three acetoxy groups, which replaced $2-\mathrm{OH}, 3-\mathrm{OH}$ and $\mathrm{H}-11$ in tabulalin $\mathrm{C}$, respectively, and lacked an acetoxy group at C-19. The methyl at C-19 was confirmed by the HMBC correlations between H-19/C-10, H-19/C-5 and H-19/C-9. The acetoxy groups at C-2, C-3 and C-11 were revealed by the HMBC correlations from $\mathrm{H}-2, \mathrm{H}-3$ and $\mathrm{H}-11$ to the corresponding carbonyl of the acetoxy group (Figure 2). The relative configuration of 4 was established to be the same as these of tabulalin C based on the explanation of ROESY correlations (Figure 3). Thus, the structure of 4 was assigned as depicted and it was named tabulalin $\mathrm{N}$. 
Table 2. ${ }^{13} \mathrm{C}-\mathrm{NMR}(125 \mathrm{MHz})$ data of compounds $1-6\left(\mathrm{CDCl}_{3}, \delta_{\mathrm{C}}\right.$ in ppm).

\begin{tabular}{|c|c|c|c|c|c|c|}
\hline Carbon & 1 & 2 & 3 & 4 & 5 & 6 \\
\hline 1 & 84.4 & 84.3 & 85.3 & 84.9 & 84.5 & 84.9 \\
\hline 2 & 83.9 & 84.1 & 80.0 & 83.2 & 77.0 & 82.9 \\
\hline 3 & 85.2 & 85.4 & 82.9 & 80.2 & 83.0 & 81.0 \\
\hline 4 & 44.8 & 44.6 & 45.4 & 46.6 & 45.9 & 46.8 \\
\hline 5 & 39.8 & 38.8 & 35.6 & 35.7 & 36.9 & 34.6 \\
\hline 6 & 33.8 & 33.3 & 33.6 & 33.1 & 32.2 & 30.9 \\
\hline 7 & 173.4 & 172.6 & 172.3 & 173.1 & 173.2 & 171.8 \\
\hline 8 & 84.1 & 84.1 & 86.0 & 78.3 & 80.5 & 79.2 \\
\hline 9 & 86.2 & 87.0 & 86.2 & 83.2 & 83.0 & 82.6 \\
\hline 10 & 48.1 & 47.7 & 45.6 & 46.3 & 47.6 & 45.7 \\
\hline 11 & 26.5 & 26.5 & 69.8 & 68.8 & 69.5 & 69.3 \\
\hline 12 & 29.2 & 29.2 & 71.4 & 70.6 & 70.3 & 69.6 \\
\hline 13 & 38.6 & 38.3 & 38.9 & 42.6 & 44.9 & 44.8 \\
\hline 14 & 153.9 & 154.1 & 42.5 & 42.5 & 43.8 & 44.2 \\
\hline 15 & 122.3 & 122.1 & 26.9 & 27.9 & 92.2 & 91.9 \\
\hline 16 & 162.3 & 163.1 & 169.9 & 167.7 & 170.1 & 169.8 \\
\hline 17 & 81.0 & 78.7 & 77.0 & 71.0 & 70.3 & 69.7 \\
\hline 18 & 21.0 & 19.5 & 15.7 & 18.0 & 18.1 & 18.0 \\
\hline 19 & 15.7 & 15.6 & 16.5 & 16.4 & 66.1 & 68.0 \\
\hline 20 & 159.5 & 133.6 & 121.3 & 121.9 & 122.2 & 121.9 \\
\hline 21 & 103.8 & 168.6 & 140.8 & 142.2 & 141.4 & 141.1 \\
\hline 22 & 124.3 & 149.0 & 110.3 & 109.9 & 110.0 & 110.1 \\
\hline 23 & 169.0 & 102.7 & 143.0 & 142.8 & 142.7 & 143.4 \\
\hline 28 & 14.6 & 14.6 & 14.3 & 14.7 & 14.5 & 14.4 \\
\hline 29 & 39.7 & 40.0 & 39.8 & 40.6 & 39.7 & 39.3 \\
\hline 30 & 74.3 & 74.0 & 70.1 & 74.1 & 73.9 & 73.6 \\
\hline 31 & 120.1 & 120.1 & 119.4 & 119.2 & 120.0 & 119.7 \\
\hline 32 & 16.7 & 16.8 & 21.3 & 21.0 & 21.0 & 20.8 \\
\hline $1^{\prime}$ & & & & & 180.1 & 180.8 \\
\hline $2^{\prime}$ & & & & & 25.9 & 25.8 \\
\hline $3^{\prime}$ & & & & & 11.3 & 11.3 \\
\hline 7-OMe & 52.4 & 52.4 & 51.9 & 52.1 & 52.1 & \\
\hline 21/23-OMe & 57.3 & 57.9 & & & & \\
\hline 2-OAc & $170.7,22.0$ & $170.7,22.0$ & & $169.5,21.9$ & & $169.6,21.8$ \\
\hline 3-OAc & $169.3,21.8$ & $169.5,21.8$ & $171.1,21.6$ & $170.3,21.0$ & $170.5,21.0$ & $169.5,21.3$ \\
\hline $\begin{array}{c}\text { 11-OAc/ } \\
\text { 11-OCOCHMe }\end{array}$ & & & & $169.5,20.8$ & $168.9,21.0$ & $\begin{array}{c}175.4,34.2 \\
18.6,19.5\end{array}$ \\
\hline $\begin{array}{c}\text { 12-OAcl } \\
\text { 12-OCOCHMe } / \\
\text { 12-OCOCHCH }{ }_{2} \text { Me }\end{array}$ & & & $\begin{array}{c}175.3,34.9 \\
19.5,18.6\end{array}$ & $169.5,19.8$ & $172.3,26.6,8.5$ & $169.8,20.0$ \\
\hline 17-OAc & & & & $168.9,21.3$ & $169.0,20.9$ & $168.9,20.7$ \\
\hline 19-OAc & & & & & $171.1,21.2$ & \\
\hline $30-\mathrm{OCOCHMe}{ }_{2}$ & & & $\begin{array}{c}175.0,33.8, \\
18.1,18.1\end{array}$ & & & \\
\hline
\end{tabular}

Compound 5, a white amorphous powder, had the molecular formula of $\mathrm{C}_{43} \mathrm{H}_{52} \mathrm{O}_{20}$ as determined by the HRESIMS ion at $m / z 911.2932\left([\mathrm{M}+\mathrm{Na}]^{+}\right.$calcd. 911.2944), which indicated 18 degrees of unsaturation. The IR absorption bands at $3451 \mathrm{~cm}^{-1}$ and $1743 \mathrm{~cm}^{-1}$ suggested the presence of hydroxy and carbonyl groups. The ${ }^{1} \mathrm{H}$ - and ${ }^{13} \mathrm{C}-\mathrm{NMR}$ data of 5 (Tables 2 and 3) showed great similarity to those of chukvelutilide A [11]. The only difference was the replacement of the 12-O-acetyl group in chukvelutilide $\mathrm{A}$ by the 12-O-propionyl group in 5, which was further confirmed by $\mathrm{HMBC}$ and ${ }^{1} \mathrm{H}-{ }^{1} \mathrm{H}$ COSY correlations as depicted in Figure 2. The relative configuration of 5 was established to be the same as that of chukvelutilide A by the ROESY spectrum (Figure 3). Therefore, the structure of $\mathbf{5}$ was elucidated and it was named chukvelutilide.

Compound 6 was obtained as a white amorphous powder. The molecular formula $\mathrm{C}_{43} \mathrm{H}_{50} \mathrm{O}_{19}$ was determined by the pseudomolecular ion peak at $m / z$ 893.2822 $\left([\mathrm{M}+\mathrm{Na}]^{+}\right.$calcd. 893.2839) in the HRESIMS, indicating 19 degrees of unsaturation. The IR spectrum of 6 displayed absorptions for hydroxy group at $3481 \mathrm{~cm}^{-1}$ and carbonyl groups at $1748 \mathrm{~cm}^{-1}$. The ${ }^{1} \mathrm{H}-$ and ${ }^{13} \mathrm{C}-\mathrm{NMR}$ data of 6 (Tables 2 and 3) were similar to those of velutinasin D [23], except for the replacements of the 
12-O-isobutyryl group and 2-OH in velutinasin $\mathrm{D}$ by the $12-\mathrm{O}$-acetyl and 2-O-acetyl in 6 . The acetoxy at C-12 $\left(\delta_{C}\right.$ 69.6) was revealed by the HMBC correlations from H-12 $\left(\delta_{\mathrm{H}} 4.72\right)$ to the corresponding carbonyl of the acetoxy group. Similarly, the acetoxy at C-2 was confirmed by the HMBC correlations (Figure 2). The relative configuration of 6 was established to be the same as that of velutinasin $\mathrm{D}$ by the ROESY spectrum (Figure 3). Thus, the structure of 6, named velutinasin J, was elucidated as shown.

Table 3. ${ }^{1} \mathrm{H}-\mathrm{NMR}(500 \mathrm{MHz})$ data of compounds $4-6\left(\mathrm{CDCl}_{3}, \delta_{\mathrm{H}}\right.$ in ppm, J in $\left.\mathrm{Hz}\right)$.

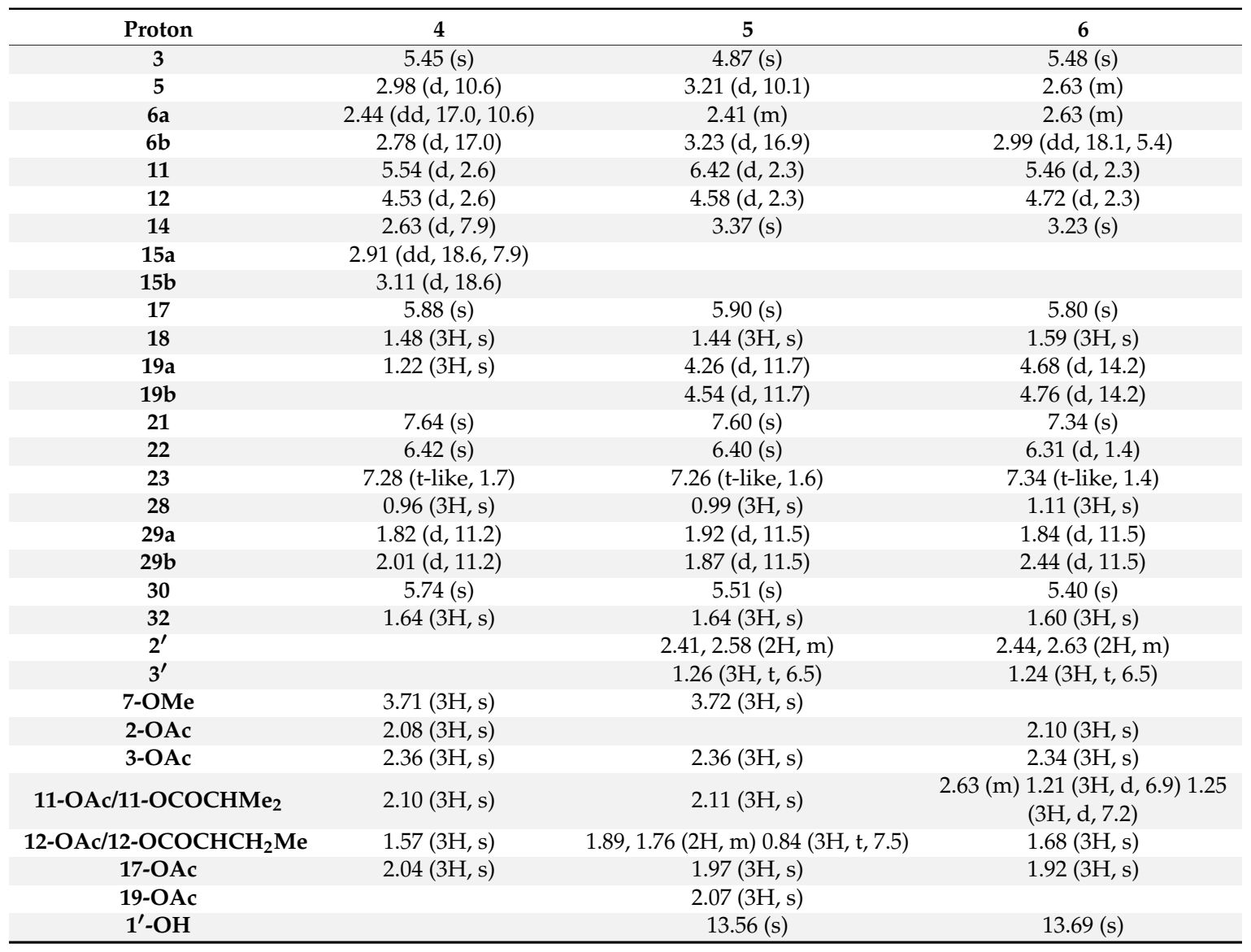

Two known compounds were identified as chukvelutilide A (7) [11] and velutinasin D (8) [23], respectively, by interpreting their NMR data and making comparisons with literature values. More details about the original spectra of NMR, IR and HRESIMS data for the new compounds 1-6 see Figures S1-S48 of the supplementary materials.

All the compounds were tested for the $\alpha$-glucosidase and acetylcholinesterase inhibition activities according to the method of Li [24] and Xiang [25]. There was no obvious inhibition effect on $\alpha$-glucosidase and acetylcholinesterase. Previous research showed that the EtOAc-soluble extract of C. tabularis and some phragmalin limonoids which were isolated from it had significant $\alpha$-glucosidase inhibitory activity [19]. Compare the chemical structures between the previously isolated limonoids with significant $\alpha$-glucosidase inhibitory activities and the newly isolated compounds, a quinary lactone ring instead of a $\beta$-furyl ring located at C-17 in compound 1 and 2, D-rings were opened and an acetoxy group was connected to C-17 in compounds $\mathbf{4 - 8}$. These differences of chemical structures might be the reason for missing the $\alpha$-glucosidase inhibitory activity of the newly isolated compounds, and were consistent with the result of our previous study [19]. 


\section{Materials and Methods}

\subsection{General Procedures}

The NMR spectra were recorded with a Bruker AV III spectrometer (Bruker, Bremen, Germany) using TMS as an internal standard. Optical rotations were measured on an MCP 5100 polarimeter (Anton Paar, Graz, Austria). The infrared spectra were recorded with a Nicolet 380 FT-IR spectrometer (Thermo, Pittsburgh, PA, USA). UV spectra were recorded on a Shimadzu UV2550 spectrophotometer (Shimadzu, Kyoto, Japan). The mass spectrometric (HRESIMS) data were acquired using an API QSTAR Pulsar mass spectrometer (Bruker, Bremen, Germany). Melting points were obtained with an apparatus of Beijing Taike X-5 (Beijing Taike Instrument Co. Ltd., Beijing, China). MCI gel CHP-20P (75-150 $\mu \mathrm{m}$; Mitsubishi Chemical Industries Co. Ltd., Tokyo, Japan), silica gel (60-80 and 200-300 mesh; Qingdao Haiyang Chemical Co. Ltd., Qingdao, China), Rp-C 18 (20-45 $\mu \mathrm{m}$; Fuji Silysia Chemical Ltd., Durham, NC, USA) and Sephadex LH-20 (40-70 $\mu \mathrm{m}$; Merck, Darmstadt, Germany) were used for column chromatography. Preparative HPLC was performed using an Agilent Technologies 1260 Infinity equipped with a YMC-packed Rp- $\mathrm{C}_{18}$ column $(5 \mu \mathrm{m}, 250 \mathrm{~mm} \times 10 \mathrm{~mm}, 4 \mathrm{~mL} / \mathrm{min})$ and an Agilent DAD G1315D detector. The solvents used to the extraction or isolation of the columns (MCI gel, Silica gel, Sephadex LH-20 and Rp- $\mathrm{C}_{18}$ columns), such as ethyl acetate, methanol, chloroform and methanol, were of analytical pure (Concord Technology Co. Ltd., Tianjin, China). The solvents used to the preparative HPLC, such as methanol and acetonitrile, were of chromatographic grade (Concord Technology Co. Ltd., Tianjin, China).

\subsection{Plant Material}

The stems of C. tabularis were collected from Haikou, Hainan Province, P.R. China, in July 2014, and identified by Dr. Jun Wang. A voucher sample (No. 20140726) was deposited at the Institute of Tropical Bioscience and Biotechnology, Chinese Academy of Tropical Agriculture Science.

\subsection{Extraction and Isolation}

The dried stems of C. tabularis $(110.0 \mathrm{~kg})$ were pulverized and extracted three times with $95 \%$ ethanol (314 L) at room temperature. The extract was concentrated under reduced pressure to afford a crude extract $\left(13.7 \mathrm{~kg}\right.$ ), followed by suspension in $\mathrm{H}_{2} \mathrm{O}$ and extraction with petroleum ether, EtOAc, and n-BuOH successively. Then, the extract solutions were evaporated to dryness under reduced pressure separately to get the petroleum ether extract (30.0 g), EtOAc extract (1700.0 g) and n-BuOH extract $(800.0 \mathrm{~g})$. The EtOAc extract $(1700.0 \mathrm{~g})$ was chromatographed on silica gel eluted with a petroleum ether-EtOAc system $(20: 1$ to $0: 1, v / v)$ to yield 18 fractions. Fr.15 (220.0 g) was further chromatographed on silica gel eluted with $\mathrm{CHCl}_{3}-\mathrm{MeOH}(50: 1, v / v)$ to yield one fraction (90.0g), followed by $\mathrm{MCI}$ gel eluting with $\mathrm{MeOH}-\mathrm{H}_{2} \mathrm{O}$ (from 4:6 to 1:0) to yield Fr.15-1-Fr.15-12. Fr.15-9 (30.0 g) was chromatographed on Sephadex LH-20 gel with MeOH to yield Fr.15-9-1-Fr.15-9-3. Fr.15-9-2 (5.0 g) was chromatographed on a reversed-phase $\mathrm{C}_{18}$ silica gel column eluted with acetonitrile- $\mathrm{H}_{2} \mathrm{O}$ (from 4:6 to 6:4) to provide eleven fractions (Fr.15-9-2-1-Fr.15-9-2-11). Fr.15-9-2-1 (140 mg) was separated by preparative HPLC [mobile phase: Acetonitrile $/ \mathrm{H}_{2} \mathrm{O}(35: 65, v / v)$; flow rate: $4 \mathrm{~mL} \cdot \mathrm{min}^{-1}$; UV detection at $214 \mathrm{~nm}$ ] to obtain compound $1\left(4.0 \mathrm{mg}, \mathrm{t}_{\mathrm{R}}=24.801 \mathrm{~min}\right)$ and compound $2\left(7.4 \mathrm{mg}, \mathrm{t}_{\mathrm{R}}=26.522 \mathrm{~min}\right)$, respectively. Fr.15-9-2-4 (400 mg) was chromatographed on a reversed-phase $\mathrm{C}_{18}$ column eluted with $\mathrm{MeOH}-\mathrm{H}_{2} \mathrm{O}$ (from 5:6 to 7:3) to give six subfractions (Fr.15-9-2-4-1-Fr.15-9-2-4-6). Fr.15-9-2-4-6 $(8 \mathrm{mg})$ was separated by preparative HPLC [mobile phase: acetonitrile $/ \mathrm{H}_{2} \mathrm{O}(57: 43, v / v)$; flow rate: $4 \mathrm{~mL} \cdot \mathrm{min}^{-1}$; UV detection at $214 \mathrm{~nm}$ ] to obtain compound 3 (2.0 $\left.\mathrm{mg}, \mathrm{t}_{\mathrm{R}}=12.014 \mathrm{~min}\right)$. Fr.15-9-2-3 (31 mg) was separated by preparative HPLC [mobile phase: $\mathrm{MeOH} / \mathrm{H}_{2} \mathrm{O}(55: 45, v / v)$; flow rate: $4 \mathrm{~mL} \cdot \mathrm{min}^{-1}$; $\mathrm{UV}$ detection at $214 \mathrm{~nm}$ ] to obtain compound 4 (7.0 $\left.\mathrm{mg}, \mathrm{t}_{\mathrm{R}}=33.912 \mathrm{~min}\right)$. Fr.15-9-2-8 $\left(170 \mathrm{mg}\right.$ ) was chromatographed on a reversed-phase $\mathrm{C}_{18}$ column eluted with $\mathrm{MeOH}-\mathrm{H}_{2} \mathrm{O}$ (from 6:4 to 7:3) to give six subfractions (Fr.15-9-2-8-1-Fr.15-9-2-8-6). Fr.15-9-2-8-5 (16 mg) was further separated by preparative HPLC [mobile phase: acetonitrile $/ \mathrm{H}_{2} \mathrm{O}(55: 45, v / v)$; flow rate: $4 \mathrm{~mL} \cdot \mathrm{min}^{-1}$; UV detection 
at $273 \mathrm{~nm}$ ] to obtain compound $5\left(4.0 \mathrm{mg}, \mathrm{t}_{\mathrm{R}}=21.674 \mathrm{~min}\right)$. Fr.15-9-2-11 (300 $\left.\mathrm{mg}\right)$ was chromatographed on silica gel eluted with a petroleum ether- $\mathrm{CHCl}_{3}$-isopropanol system $(100: 40: 1$ to 40:40:1, v/v/v) to yield three subfractions (Fr.15-9-2-11-1-Fr.15-9-2-11-3). Fr.15-9-2-11-2 (78 mg) was further separated by preparative HPLC [mobile phase: $\mathrm{MeOH} / \mathrm{H}_{2} \mathrm{O}(72: 28, v / v)$; flow rate: $4 \mathrm{~mL} \cdot \mathrm{min}^{-1}$; UV detection at $273 \mathrm{~nm}$ ] to obtain compound $6\left(14.0 \mathrm{mg}, \mathrm{t}_{\mathrm{R}}=10.340 \mathrm{~min}\right)$. Fr.15-9-2-11-3 (58 $\left.\mathrm{mg}\right)$ was separated by preparative HPLC [mobile phase: $\mathrm{MeOH} / \mathrm{H}_{2} \mathrm{O}(73: 27, v / v)$; flow rate: $4 \mathrm{~mL} \cdot \mathrm{min}^{-1}$; UV detection at $273 \mathrm{~nm}$ ] to obtain compound $8\left(12.0 \mathrm{mg}, \mathrm{t}_{\mathrm{R}}=14.010 \mathrm{~min}\right)$. Fr.15-9-2-5 (770 $\left.\mathrm{mg}\right)$ was first subjected to a reversed-phase $\mathrm{C}_{18}$ column eluted with $\mathrm{MeOH}-\mathrm{H}_{2} \mathrm{O}$ (from 5:5 to 7:3) to give eight subfractions (Fr.15-9-2-5-1-Fr.15-9-2-5-8). Fr.15-9-2-5-6 (88 mg) was separated by preparative HPLC [mobile phase: $\mathrm{MeOH} / \mathrm{H}_{2} \mathrm{O}(65: 35, v / v)$; flow rate: $4 \mathrm{~mL} \cdot \mathrm{min}^{-1}$; UV detection at $273 \mathrm{~nm}$ ] to obtain compound 7 $\left(20.0 \mathrm{mg}, \mathrm{t}_{\mathrm{R}}=13.467 \mathrm{~min}\right)$.

Moluccensin $Z 1$ (1): White amorphous powder; m.p. $153-157^{\circ} \mathrm{C} ;[\alpha]_{\mathrm{D}}^{25}=+61.3^{\circ}(c 0.08, \mathrm{MeOH})$; IR $(\mathrm{KBr}) v_{\max } 3528,2924,1731,1457,1372,1260,1094,801,736 \mathrm{~cm}^{-1} ;{ }^{1} \mathrm{H}$ - and ${ }^{13} \mathrm{C}-\mathrm{NMR}$ data see Tables 1 and 2; positive-mode HRESIMS $m / z$ 711.2274 $[\mathrm{M}+\mathrm{Na}]^{+}$(calcd. for $\mathrm{C}_{34} \mathrm{H}_{40} \mathrm{O}_{15} \mathrm{Na}$, 711.2259).

Moluccensin Z2 (2): White amorphous powder; m.p. $155-157^{\circ} \mathrm{C}$; $[\alpha]_{\mathrm{D}}^{25}=+85.0^{\circ}(c 0.08, \mathrm{MeOH})$; IR $(\mathrm{KBr}) \nu_{\max } 3545,2925,1734,1458,1371,1260,1027,801,737 \mathrm{~cm}^{-1} ;{ }^{1} \mathrm{H}$ - and ${ }^{13} \mathrm{C}-\mathrm{NMR}$ data see Tables 1 and 2; positive-mode HRESIMS $m / z 711.2260[\mathrm{M}+\mathrm{Na}]^{+}$(calcd. for $\mathrm{C}_{34} \mathrm{H}_{40} \mathrm{O}_{15} \mathrm{Na}$, 711.2259).

Carapanolide $Y$ (3): White amorphous powder; m.p. $120-123{ }^{\circ} \mathrm{C} ;[\alpha]_{\mathrm{D}}^{25}=-36.3^{\circ}(c 0.08, \mathrm{MeOH}) ; \lambda_{\max }$ $(\log \varepsilon) 306(2.61) \mathrm{nm} ; \mathrm{IR}(\mathrm{KBr}) v_{\max } 3557,2924,1736,1467,1372,1260,1026,801 \mathrm{~cm}^{-1} ;{ }^{1} \mathrm{H}$ - and ${ }^{13} \mathrm{C}-\mathrm{NMR}$ data see Tables 1 and 2; positive-mode HRESIMS $m / z$ 797.3017 [M + Na] ${ }^{+}$(calcd. for $\mathrm{C}_{39} \mathrm{H}_{50} \mathrm{O}_{16} \mathrm{Na}_{\text {, }}$ 797.2991).

Tabulalin N (4): White amorphous powder; m.p. $162-164{ }^{\circ} \mathrm{C} ;[\alpha]_{\mathrm{D}}^{25}=-20.0^{\circ}(c 0.20, \mathrm{MeOH}) ; \lambda_{\max }(\log \varepsilon)$ 264 (2.92) nm; IR (KBr) $v_{\max } 2923,1750,1372,1217,1026,801 \mathrm{~cm}^{-1},{ }^{1} \mathrm{H}$ - and ${ }^{13} \mathrm{C}-\mathrm{NMR}$ data see Tables 2 and 3; positive-mode HRESIMS $m / z$ 825.2588 [M + Na] $]^{+}$(calcd. for $\mathrm{C}_{39} \mathrm{H}_{46} \mathrm{O}_{18} \mathrm{Na}$, 825.2576).

Chukvelutilide A1(5): White amorphous powder; m.p. 139-142 ${ }^{\circ} \mathrm{C} ;[\alpha]_{\mathrm{D}}^{25}=-21.3^{\circ}(c 0.08, \mathrm{MeOH}) ; \lambda_{\max }$ $(\log \varepsilon) 203$ (3.86), 237 (3.32), 268 (3.57) nm; IR (KBr) $v_{\max } 3451,2918,1743,1373,1218,1026,801 \mathrm{~cm}^{-1}$; ${ }^{1} \mathrm{H}$ - and ${ }^{13} \mathrm{C}-\mathrm{NMR}$ data see Tables 2 and 3; positive-mode HRESIMS $\mathrm{m} / z$ 911.2932 [M + Na] ${ }^{+}$(calcd. for $\left.\mathrm{C}_{43} \mathrm{H}_{52} \mathrm{O}_{20} \mathrm{Na}, 911.2944\right)$.

Velutinasin J (6): White amorphous powder; m.p. $169-171{ }^{\circ} \mathrm{C} ;[\alpha]_{\mathrm{D}}^{25}=-3.5^{\circ}(c 0.20, \mathrm{MeOH}) ; \lambda_{\max }$ $(\log \varepsilon) 234$ (3.43), 269 (3.80) nm; IR (KBr) $v_{\max } 3481,2923,1748,1604,1371,1224,1027,800 \mathrm{~cm}^{-1} ;{ }^{1} \mathrm{H}_{-}$ and ${ }^{13} \mathrm{C}-\mathrm{NMR}$ data see Tables 2 and 3; positive-mode HRESIMS $m / z$ 893.2822 [M + Na] ${ }^{+}$(calcd. for $\left.\mathrm{C}_{43} \mathrm{H}_{50} \mathrm{O}_{19} \mathrm{Na}, 893.2839\right)$.

Supplementary Materials: The following are available online. 1D- and 2D-NMR, IR, as well as HRESIMS spectra of Compounds 1-6.

Author Contributions: Y.-C.W. performed the isolation and structure elucidation of the compounds. F.-D.K., H.W. and W.-L.M. contributed in the interpretation of the spectra and also part of the preparation of the manuscript. S.-B.L. and Y.-X.Z. partially contributed the structure elucidation, analyzed the data and together with Y.-C.W. prepared the manuscript. H.-F.D. planned, designed and organized the whole research of this study. All authors approved the final version of the manuscript.

Funding: This research was financially supported by a grant from the Postdoctoral General Program of Hainan Province, Central Public-interest Scientific Institution Basal Research Fund for Innovative Research Team Program of CATAS (17CXTD-15), The Innovative Research Team Grant of the Natural Science Foundation of Hainan Province (No. 2017CXTD020), and China Agriculture Research System (CARS-21).

Conflicts of Interest: The authors declare no conflict of interest.

\section{References}

1. Chen, S.K.; Chen, B.Y.; Li, H. Flora republicae popularis sinicae. In Chinese Flora (Zhongguo Zhiwu Zhi); Science Press: Beijing, China, 1997; pp. 47-49. 
2. Editorial Committee of the Administration Bureau of Traditional Chinese Medicine. Chemical composition and structure. In Chinese Material Medica (Zhonghua Bencao), 1st ed.; Shanghai Science and Technology Press: Shanghai, China, 1999; Volume 5, pp. 31-32.

3. Tan, Q.G.; Luo, X.D. Meliaceous limonoids: Chemistry and biological activities. Chem. Rev. 2011, 111, 7437-7522. [CrossRef] [PubMed]

4. Luo, J.; Wang, J.S.; Luo, J.G.; Wang, X.B.; Kong, L.Y. Velutabularins A-J, phragmalin-type limonoids with novel cyclic moiety from Chukrasia tabularis var. velutina. Tetrahedron 2011, 67, 2942-2948. [CrossRef]

5. Luo, J.; Li, Y.; Wang, J.S.; Lu, J.; Kong, L.Y. Three new C-15-isobutyryl 16-norphragmalin-type limonoids from Chukrasia tabularis var. velutina. Phytochem. Lett. 2012, 5, 249-252. [CrossRef]

6. Liu, J.Q.; Peng, X.R.; Zhang, W.M.; Shi, L.; Li, X.Y.; Chen, J.C.; Qiu, M.H. Swietemahalactone, a rearranged phragmalin-type limonoid with anti-bacterial effect, from Swietenia mahagoni. RSC Adv. 2013, 3, 4890-4893. [CrossRef]

7. Nakatani, M.; Abdelgaleil, S.A.M.; Saad, M.M.G.; Huang, R.C.; Doe, M.; Iwagawa, T. Phragmalin limonoids from Chukrasia tabularis. Phytochemistry 2004, 65, 2833-2841. [CrossRef] [PubMed]

8. Luo, J.; Wang, J.S.; Wang, X.B.; Luo, J.G.; Kong, L.Y. Phragmalin-type limonoid orthoesters from Chukrasia tabularis var. velutina. Chem. Pharm. Bull. 2011, 59, 225-230. [CrossRef] [PubMed]

9. Luo, J.; Wang, J.S.; Cao, W.J.; Kong, L.Y. A new phragmalin-type limonoid from Chukrasia tabularis var. velutina. Chin. J. Nat. Med. 2011, 9, 98-100.

10. Fan, C.Q.; Wang, X.N.; Yin, S.; Zhang, C.R.; Wang, F.D.; Yue, J.M. Tabularisins A-D, phragmalin ortho esters with new skeleton isolated from the seeds of Chukrasia tabularis. Tetrahedron 2007, 63, 6741-6747. [CrossRef]

11. Luo, J.; Wang, J.S.; Wang, X.B.; Huang, X.F.; Luo, J.G.; Kong, L.Y. Chukvelutilides A-F, phragmalin limonoids from the stem barks of Chukrasia tabularis var. velutina. Tetrahedron 2009, 65, 3425-3431. [CrossRef]

12. Luo, J.; Wang, J.S.; Wang, X.B.; Luo, J.G.; Kong, L.Y. Chuktabularins E-T, 16-Norphragmalin Limonoids from Chukrasia tabularis var. velutina. J. Nat. Prod. 2010, 73, 835-843. [CrossRef] [PubMed]

13. Zhang, C.R.; Yang, S.P.; Liao, S.G.; Fan, C.Q.; Wu, Y.; Yue, J.M. Chuktabularins A-D, four new limonoids with unprecedented carbon skeletons from the stem bark of Chukrasia tabularis. Org. Lett. 2007, 9, 3383-3386. [CrossRef] [PubMed]

14. Luo, J.; Wang, J.S.; Luo, J.G.; Wang, X.B.; Kong, L.Y. Chukvelutins A-C, 16-norphragmalin limonoids with unprecedented skeletons from Chukrasia tabularis var. velutina. Org. Lett. 2009, 11, 2281-2284. [CrossRef] [PubMed]

15. Yin, J.L.; Di, Y.T.; Fang, X.; Liu, E.D.; Liu, H.Y.; He, H.P.; Li, S.L.; Li, S.F.; Hao, X.J. Tabulvelutin A, the first 19-nor limonoid with unprecedented ring system from Chukrasia tabularis var. velutina. Tetrahedron Lett. 2011, 52, 3083-3085. [CrossRef]

16. Liu, H.B.; Zhang, H.; Li, P.; Gao, Z.B.; Yue, J.M. Chukrasones A and B: Potential Kv1.2 potassium channel blockers with new skeletons from Chukrasia tabularis. Org. Lett. 2012, 14, 4438-4441. [CrossRef] [PubMed]

17. Ragettli, T.; Tamm, C. Die Chukrasine A, B, C, D und E, fünf neue Tetranortriterpene aus Chukrasia tabularis A. Juss. Helv. Chim. Acta 1978, 61, 1814-1831. [CrossRef]

18. Zhang, C.R.; Fan, C.Q.; Zhang, L.; Yang, S.P.; Wu, Y.; Lu, Y.; Yue, J.M. Chuktabrins A and B, two novel limonoids fom the twigs and leaves of Chukrasia tabularis. Org. Lett. 2008, 10, 3183-3186. [CrossRef] [PubMed]

19. Peng, J.L.; Wang, J.; Kong, F.D.; Liu, Z.Q.; Wang, P.; Gai, C.J.; Jiang, B.; Mei, W.L.; Dai, H.F. New phragmalin-type limonoids from Chukrasia tabularis and their $\alpha$-glucosidase inhibitory activity. Molecules 2016, 21, 58. [CrossRef] [PubMed]

20. Li, J.; Li, M.Y.; Feng, G.; Zhang, J.; Karonen, M.; Sinkkonen, J.; Satyanandamurty, T.; Wu, J. Moluccensins $\mathrm{R}-\mathrm{Y}$, limonoids from the seeds of a mangrove, Xylocarpus moluccensis. J. Nat. Prod. 2012, 75, 1277-1283. [CrossRef] [PubMed]

21. Inoue, T.; Matsui, Y.; Kikuchi, T.; Yamada, T.; In, Y.; Muraoka, O.; Sakai, C.; Ninomiya, K.; Morikawa, T.; Tanaka, R. Carapanolides Me-S from seeds of andiroba (Carapa guianensis, Meliaceae) and triglyceride metabolism-promoting activity in high glucose-pretreated HepG2 cells. Tetrahedron 2015, 71, 2753-2760. [CrossRef]

22. Luo, J.; Li, Y.; Wang, J.S.; Kong, L.Y. D-ring-opened phragmalin-type limonoids from Chukrasia tabularis var. velutina. Chem. Biodivers. 2011, 8, 2261-2269. [CrossRef] [PubMed] 
23. Zhang, F.; Zhang, C.R.; Tao, X.; Wang, J.; Chen, W.S.; Yue, J.M. Phragmalin-type limonoids with NF-kB inhibition from Chukrasia tabularis var. velutina. Bioorg. Med. Chem. Lett. 2014, 24, 3791-3796. [CrossRef] [PubMed]

24. Li, T.; Zhang, X.D.; Song, Y.W.; Liu, J.W. A microplate-based screening method for alpha-glucosidase inhibitors. Chin. J. Clin. Pharmacol. Ther. 2005, 10, 1128-1134.

25. Xiang, P.; Mei, W.L.; Chen, H.Q.; Kong, F.D.; Wang, H.; Liao, G.; Zhou, L.M.; Dai, H.F. Four new bi-phenylethylchromones from artificial agarwood. Fitoterapia 2017, 120, 61-66. [CrossRef] [PubMed]

Sample Availability: Samples of the compounds 1-8 are available from the authors.

(C) 2018 by the authors. Licensee MDPI, Basel, Switzerland. This article is an open access article distributed under the terms and conditions of the Creative Commons Attribution (CC BY) license (http:/ / creativecommons.org/licenses/by/4.0/). 